DOI: $10.19195 / 0137-1134.109 .21$

\title{
CLASSIFICATION OF CHOSEN OECD COUNTRIES ACCORDING TO THEIR DIDACTIC EFFICIENCY WITH THE USAGE OF TAXONOMIC MEASURE OF DEVELOPMENT
}

\section{INTRODUCTION}

The level of education has always indicated the number of educated people that could follow, repossess and adapt technical development and constituted human capital that influenced economic development ${ }^{1}$. Technical development have forced to transform traditional occupations and create new ones so it became necessary to educate, train and re-skill workers. All actions that were conducted towards speeding up economic development must have assumed parallel effort in the area of education ${ }^{2}$.

In all European Union countries central government play a very significant role in creating regulations, aims and rules of education ${ }^{3}$. Although education system is rather similar all over the world there are few elements that are not common $^{4}$. In 2010 member countries together with European Commission incorporated education and trainings as key elements in new strategy of 'Europe 2020'. This document encompasses long term aims and constitutes a basis for European cooperation on education and training area ${ }^{5}$. One of the areas in this strategy is an economic development based on knowledge and innovations. An increase in this area requires high expenditures on research and development and usage of mechanisms that foster fast transmission of theoretical knowledge to economy. Due to the fact that economy is based on knowledge and does not exist without

${ }^{1}$ M. Brzozowski, W. Siwiński, Edukacja i wzrost gospodarczy: porównania międzynarodowe. Materiały Seminaryjne: Ekonomiczne i społeczne niedostatki edukacyjne, Warszawa 2005.

2 J. Grodzicki, Edukacja czynnikiem rozwoju gospodarczego, Torun 2000.

3 D. Graniewska, Kapitat ludzki jako cel strategiczny polityki społecznej, Warszawa 1999.

${ }^{4}$ Strategia rozwoju szkolnictwa wyższego w Polsce do roku 2010, www.men.waw.pl.

${ }^{5}$ Lifelong Learning: The contribution of education systems in the Member States of the European Union, Lisbon 2000. 
educated society means that this aim can only be realized with an assumption about development and quality raising of the whole educational system ${ }^{6}$. In economy conditions and globalisation of competition significance effective usage of resources becomes vital. This situation determines the need for efficiency analyses. Efficiency measurement is vital not only for economic units but also for those that work under specific circumstances, as far as economy is concerned, for instance universities. Efficiency evaluation in a quantitative scope should constitute one of tools for making economic decisions. The more precise the more thorough the economic information is.

The aim of this article is to measure the level of didactic efficiency of chosen OECD countries and their classification according to a level in 2014. In this analysis a taxonomic measure of efficiency was used and it was based on data from Eurostat bases and OECD. While choosing variables the informative values of characteristics were taken into consideration and what they contribute to the study because this will influence the quality of synthetic measure ${ }^{7}$, which was created in an analytical part of a study.

\section{TAXONOMIC MEASURE OF EFFICIENCY AND A METHOD OF A DEVELOPMENT MODEL}

In empirical studies all analysed units are described with the usage of more than one characteristics and multidimensional methods of comparative analysis are used. It analyses so called 'complex phenomena', those that are described with the usage of at least two variables. Methods of multidimensional comparative analyses allow for various rankings of multidimensional objects ${ }^{8}$. They are from a group of so called taxonomic method and their aim is to compare objects by:

— clearing the set of objects;

- grouping sets of objects in subsets of elements similar to each other on the basis of their characteristics

— the choice of representatives of obtained group of objects ${ }^{9}$.

${ }^{6}$ M. Sulmicka, Ekspertyza. Priorytety i cele rozwojowe UE do roku 2020 w kontekście aktualizacji średniookresowej strategii rozwoju kraju, http://www.mrr.gov.pl/rozwoj_regionalny/ Polityka_rozwoju/SRK/Ekspertyzy_aktualizacja_SRK_1010/Documents/Ekspertyza20_Prof_ Sulmicka_08122010.pdf.

7 A. Zeliaś, Proste metody oceny ważności zmiennych diagnostycznych, „Zeszyty Naukowe AE” nr 440, Kraków 1994.

8 T. Panek, J. Zwierzchowski, Statystyczne metody wielowymiarowej analizy porównawczej. Teoria i zastosowania, Warszawa 2013, p. 15.

${ }^{9}$ M. Łuniewska, W. Tarczyński, Metody wielowymiarowej analizy porównawczej na rynku kapitałowym, Warszawa 2006, p. 10. 
Multidimensional comparative analysis determines vector of variables:

$$
\mathrm{X}=\left[\mathrm{X}_{1}, \mathrm{X}_{2}, \ldots, \mathrm{X}_{\mathrm{k}}\right]
$$

where $k$ is a number of variables ${ }^{10}$. Due to the fact that each variable takes $n$ value, so a matrix of observation for a group of such objects is described as:

$$
X=\left[\begin{array}{ccccc}
x_{11} & x_{12} & x_{13} & \cdots & x_{1 k} \\
x_{21} & x_{22} & x_{23} & \cdots & x_{2 k} \\
x_{31} & x_{32} & x_{33} & \cdots & x_{3 k} \\
\vdots & \vdots & \vdots & \ddots & \vdots \\
x_{n 1} & x_{n 2} & x_{n 3} & \cdots & x_{n k}
\end{array}\right]
$$

where $x_{i j}$ is a value of $j$-variable in $i$-object.

A very important element of multidimensional analysis is a proper choice of diagnostic characteristics. From a set of potential variables you need to find the best group in respect of:

- merit, in which expert knowledge constitutes a basis for in relations of particular characteristics with analysed complex phenomenon;

- formal, in which objective (quantitive) analysis of property is conducted for particular characteristics for a set of objects.

In a first attempt, on the basis of experts' knowledge and literature sources first selection of diagnostics characteristics is made in a set of potential variables with reference to merit connections both with objects and the aim of a study. In a second attempt further selection is conducted with the usage of statistical method ${ }^{11}$.

Characteristics taken into consideration in a description of a complex phenomenon should be characterized by variability and should not copy information.

As to categorize a variable to a properly chosen set of characteristics it must be characterized by a specific level of differentiation of its values for particular objects so it cannot be constant and it cannot be so called quasi-constant. The most common measure to evaluate a level of differentiation of objects is a factor of data changeability ${ }^{12}$ :

$$
V_{j}=\frac{S_{j}}{\bar{X}_{j}}
$$

where $\bar{X}_{j}$ - arithmetic mean of $j$-variable

$S_{j}$ - standard deviation of $j$-variable.

10 J. Dziechciarz, Ekonometria. Metody, przyktady, zadania, Wrocław 2002, p. 250.

11 Zastosowanie metod ekonometryczno-statystycznych $w$ zarządzaniu finansami zakładów ubezpieczeń, ed. W. Ronka-Chmielowiec, Wrocław 2004, p. 380.

12 Ibid., p. 381. 
Similarity of characteristics is determined on the basis of matrix of factors of Pearson correlation. The most effective way to determine correlation of data set is a coefficient of Pearson line correlation calculated according to a pattern ${ }^{13}$ :

$$
r_{X, Y}=\frac{\sum_{i=1}^{n}\left(x_{i}-\bar{x}\right)\left(y_{i}-\bar{y}\right)}{\sqrt{\sum_{i=1}^{n}\left(x_{i}-\bar{x}\right)^{2} \cdot \sum_{i=1}^{n}\left(y_{i}-\bar{y}\right)^{2}}}
$$

where $\bar{x}$ - means value of $X$ characteristics,

$\bar{y}$ - means value of $Y$ characteristics.

It is believed that diagnostic characteristics that will finally be chosen to describe a complex phenomenon should be characterized by:

- weak correlation between each other because in this situation they do not copy the information

- strong correlation between the remaining characteristics which were not chosen for a final set of diagnostic variables because they are not accurate representatives of dismissed characteristics ${ }^{14}$.

In a classical method of variables choice the basic parameter used in this procedure is a critical value of correlation coefficient. This value is helpful while choosing variables which should be taken into consideration in a linear model or in a multidimensional comparative analysis. A critical value of correlation coefficient is determined on the basis of a pattern ${ }^{15}$ :

$$
r^{*}=\sqrt{\frac{t_{\alpha}^{2}}{t_{\alpha}^{2}+n-2}},
$$

where $t$ - value of statistics taken from test tables, $t$ - students for a given level of vitality $\alpha$ and for $(n-2)$ levels of latitude; $n$ - a number of descriptive variables. Descriptive variables will be chosen in a following way:

1) from a set of all descriptive variables we eliminate those that are not correlated in a vital way with an elucidated variable which means that when

$$
\left|r_{j}\right| \leqslant \mathrm{r} .
$$

2) From the remaining variables as an elucidating we choose such variable $X_{h}$, for which $\left|r_{h}\right|=\max \left|r_{j}\right|$, because variable $X_{h}$ carries a lot of information about an elucidated variable.

13 E. Nowak, Metody taksonomiczne w klasyfikacji obiektów społeczno-gospodarczych, Warszawa 1990, p. 38.

14 Zastosowanie metod ekonometryczno-statystycznych..., p. 382

15 P.H. Ramsey, "Critical Values for Spearman's Rank Order Correlation”, Journal of Educational Statistics 14, 1989, nr 3, pp. 245-253. 
3) Then from a set of the remaining variables we should eliminate all variables that are too strongly correlated with a variable $X_{h}$, so those that copy information that have already been given. So as to do it you should use the following dependency:

$$
\left|r_{h i}\right|>\mathrm{r}^{*}
$$

In a situation when in a group there are variables you should go to point 2) of a procedure and follow it analogically as before. This should stop when there is nothing in a set of potential elucidating variables ${ }^{16}$.

Variables from a set of so called diagnostic variables set may in a very differentiated way influence the researched phenomenon. From the point of view of multidimensional analysis it is vital to define a character of all diagnostic characteristics which describe this phenomenon.

In literature of a theme we can distinguish three main types of variables. They are:

- stimulants,

- destimulants,

- nominants.

A variable is a stimulant when its growth indicates a growth of complex phenomenon. This means that high results of stimulants create a better situation for a researched variable and low values are undesirable. Destimulants are contrast to stimulants. A variable is a stimulant when a decrease of its value indicates that a level of complex phenomenon is increasing. A nominant is a variable which takes the best value in a certain open interval. It means that a value under and over a given level is a reflection of a low level of a complex phenomenon ${ }^{17}$.

In taxonomic researches a basic step is to analyse if a set of variables have characteristics of a stimulant type. (compare Ekonometria. Metody, przyktady, zadania, ed. J. Dziechciarz).

Another and inevitable step is to normalize variables. The aim of these normalizations is to reduce all variables to values that are comparable so to deprive them of names and to standardise orders of magnitude. Normalization is done for variables measured in an interval and numerical scale. A process of normalization of variables uses formulas of standardization and unitarization for variables measured on an interval scale and quotient transformations for variables measured on quotient scale. A process of normalization is a process of transformation of input variables in such a way that they have the same dispersion measured by the usage of standard deviation or with the usage of a range. The most often used techniques of normalization is a standardization which is given by a pattern ${ }^{18}$.

16 J. Dziechciarz, op. cit., pp. 47-48.

17 J. Dziechciarz, op. cit., p. 250.

18 Zastosowanie metod ekonometryczno-statystycznych..., p. 387. 


$$
Z_{i j}=\frac{X_{i j}-\bar{X}_{j}}{S_{j}}
$$

where $Z_{i j}$ is a normalized (standardized) value of $j$-variable of an $i$-object

$\bar{X}_{j}$ is an arithmetic mean of $j$-characteristics,

$S_{j}$ is a standard deviation of $j$-characteristics.

In a method of a pattern development it is assumed that values of variables are normalized and they have a stimulant character. This is a three stages method. They are as follows.

Stage I: At the beginning you should indicate an abstract object, so called a pattern of development $Z_{0}^{+}$with the best values for each variable ${ }^{19}$ :

where

$$
Z_{0}^{+}=\left[Z_{01}^{+}, Z_{02}^{+}, \ldots, Z_{0 k}^{+}\right],
$$

$$
Z_{0 j}^{+}=\max _{i} Z_{i j} \quad j=1,2, \ldots, k
$$

and an anti-pattern $Z_{0}^{-}$with the weakest values of each variable.

It is determined in a following way:

where

$$
Z_{0}^{-}=\left[Z_{01}^{-}, Z_{02}^{-}, \ldots, Z_{0 k}^{-}\right]
$$

$$
Z_{0 j}^{-}=\max _{i} Z_{i j} \quad j=1,2, \ldots, k .
$$

A pattern of development is usually a point of coordinates which are maximum realizations of particular characteristics that were normalized in an analysed set of objects. An anti-pattern is a point of coordinates that are minimal realizations of normalized characteristics in a set of objects that is analysed. ${ }^{20}$

Stage II: Next you should analyse similarities of objects for the best object by estimating a Euclid distance of each analysed object from a previously distinguished development pattern using the formula:

$$
d_{i 0}=\sqrt{\sum_{i=1}^{k}\left(Z_{i j}-Z_{0 j}\right)^{2}} \quad i=1,2, \ldots, n
$$

where $d_{i 0}$ - Euclid distance of an $i$-object from a development pattern.

The more similar the object is to a development patter the less distant is from it and the more beneficial the level of a complex phenomenon for an analysed object is.

19 J. Dziechciarz, op. cit., pp. 291-292.

20 Zastosowanie metod ekonometryczno-statystycznych..., p. 397. 
Stage III: The last stage means that for each object so called measurement of development is applied according a formula:

$$
m_{i}=1-\frac{d_{i 0}}{d_{0}},(i=1,2, \ldots, n)
$$

where $m_{i}$ - measurement of development for an $i$ object

$d_{0}$ - distance between a pattern of development and an anti-pattern:

$$
d_{0}=\sqrt{\sum_{j=1}^{k}\left(Z_{0 j}^{+}-Z_{0 j}^{-}\right)^{2}}
$$

A created measurement of development complies with the following conditions:

- the higher the level of a complex phenomenon the higher a value of a development measurement is

— values of development measurements belong to a range [0;1], but calculated measurement of development for a pattern equals 1 and for an anti-pattern $-0^{21}$.

Taxonomic measurements of development serve as a description of an analysed object with many characteristics by the usage of one aggregated value. Due to this a classification of objects, social and economic, is a division of objects with the usage of one variable. A starting point of a classification method is a set of objects arranged according to a non-decreasing value of a development measurement. In the most often encountered method of taxonomic classification of objects the two parameters are used. They are as follows: arithmetic mean $\bar{z}$ and a standard deviation $s_{z}$. On the basis of these parameters we can divide a set of objects into four groups which include objects that belong to the following ranges:

- group I: $z_{i} \geqslant \bar{z}+s_{z}$

- group II: $\bar{z}+s_{z}>z_{i} \geqslant \bar{z}$,

- group III: $\bar{z}>z_{i} \geqslant \bar{z}-s_{z}$,

- group IV: $z_{i}<\bar{z}-s_{z}^{22}$.

\section{A SITUATION OF HIGHER EDUCATION IN COUNTRIES OF EUROPEAN UNION IN 2014}

In a study on didactic efficiency in chosen OECD countries data from Eurosat and OECD was used. The research based on data from 2014. As diagnostic variables four informative indicators were used. They informed about efficiency of higher education. While choosing them it was important that they are: vital, explicit, available and complete. Into consideration were taken:

21 Ibid.

22 E. Nowak, Metody taksonomiczne w klasyfikacji obiektów społeczno-gospodarczych, Warszawa 1990, pp. 92-93. 
- the number of academic teachers for 100 students (X1);

— the amount of financing from a country for higher education for 100 stu$\operatorname{dents}(\mathrm{X} 2)$;

- the number of students for 100 citizens (X3);

— the number of graduates for 100 citizens (X4).

An analysis of all variables informs separately about a state of results in an area of didactics in particular countries of the Union.

Education is one of the most important development factors of a contemporary economy and is a tool for its modernization. Expenditures for education have a key meaning for creating competitive economy and in long-term development and building a position of a country in the world. Major development factor of education is financial help from a state due to which universities are able to manage a didactical process in an effective way. This kind of help was expressed by expenditures on education.

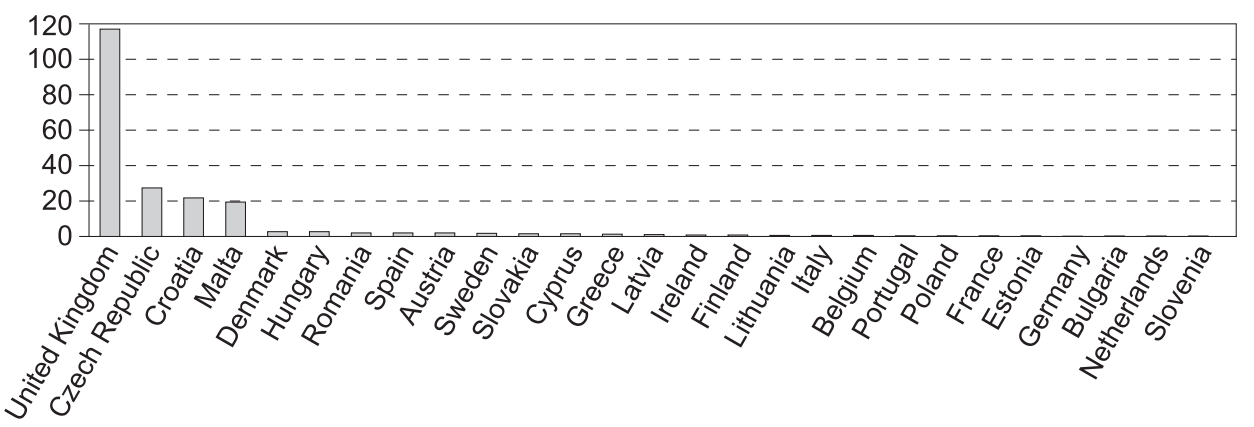

Chart 1. The amount of a state grant on higher education for 100 students

Source: Self-study

It is visible that in Great Britain, the Czech Republic and Croatia they had the highest financing from a state budget on education. Countries in which state grants are significantly under average mean are Slovenia, the Netherlands and Bulgaria. Poland is not characterized as a country with high state financing on higher education.

Another variables have a stimulant character and influence financial efficiency. Variables refer to inputs such as the number of academic teacher for 100 students and the number of students and graduates for 100 citizens of each country. In 2014 the best situation of didactic staff was in Austria (Chart 2), where for 100 there were 16 teachers. A similar situation was in Germany (13) and in Malta (12). The smaller number of academic teachers was in Greece (2), the Czech Republic $(3,8)$ and in Bulgaria $(3,9)$. In Poland for 100 students there were 5 teachers. 
In case of the number of students and graduates Poland is not a leading country in an analysed set. There are only 4 students for 100 citizens and in case of graduates the number is even lower, only 0,42 .

Bulgaria, the Netherlands and Rumania are the leading countries as far as the number of students in 2014 is concerned. The highest number of graduates in 2014 was registered in Finland, Cyprus and Croatia.

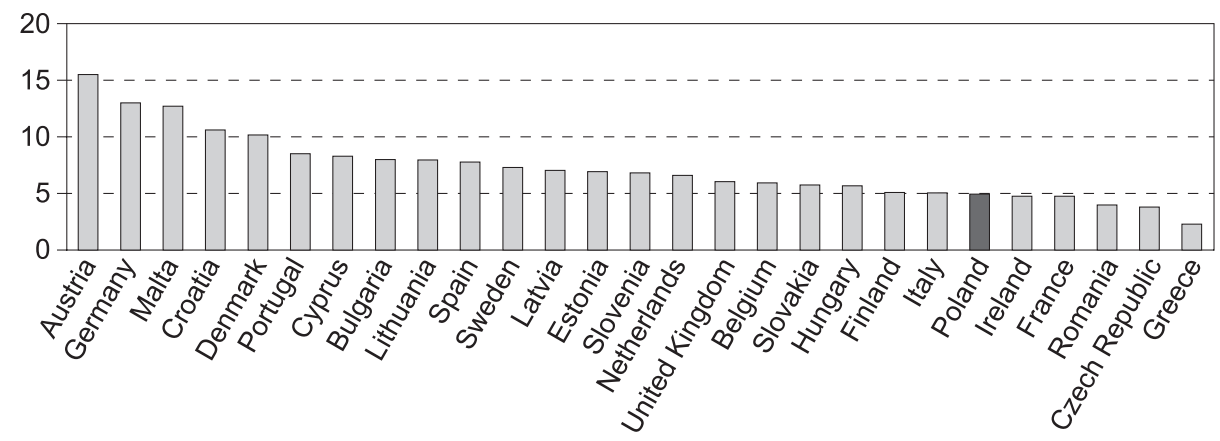

Chart 2. The number of academic teachers for 100 students

Source: Self-study
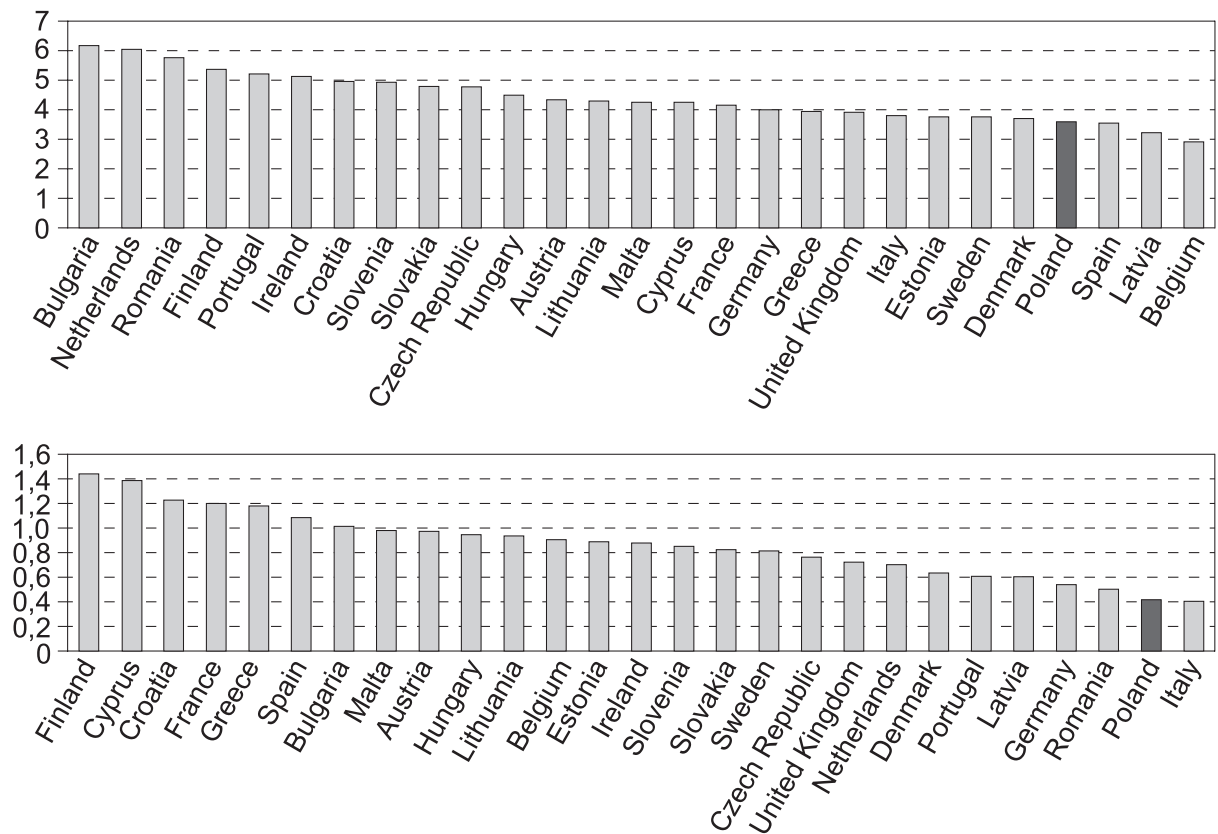

Chart 3. The number of students and graduates for 100 citizens

Source: Self-study 


\section{THE USAGE OF A MULTIDIMENSIONAL METHOD OF A COMPARATIVE ANALYSIS IN AN ANALYSIS OF DIDACTIC EFFICIENCY IN EUROPEAN UNION}

The usage of tools of multidimensional comparative analysis by creating a synthetic measurement allows to compare an average level of education on higher education level between countries and to segregate them due to their efficiency in this area. The basis of each method of linear segregation is a correct choice of diagnostics variables so variables that in a significant way characterise a complex phenomenon. An initial set of characteristics which was previously proposed was characterised by huge variability of data (Table 1).

Table 1. Basic descriptive statistics of diagnostic variables

\begin{tabular}{|l|c|c|c|c|}
\hline & $\mathrm{X} 1$ & $\mathrm{X} 2$ & $\mathrm{X} 3$ & $\mathrm{X} 4$ \\
\hline mean & 7,286 & 7,760 & 4,340 & 0,883 \\
\hline standard deviation & 3,048 & 22,879 & 0,821 & 0,279 \\
\hline Variability coefficient & $41,83 \%$ & $294,84 \%$ & $18,91 \%$ & $31,61 \%$ \\
\hline
\end{tabular}

Source: Self-study

Due to the fact that these variables had a stimulant character in another step only normalization of data was conducted. A proposed set of normalized variables constituted a representation of researched phenomenon because variables were not correlated with each other in a significant way (Table 2).

Table 2. Matrix of Pearson correlation coefficients for normalized diagnostics variables

\begin{tabular}{|c|c|c|c|c|}
\hline & \multicolumn{4}{|c|}{ Critical value (with bilateral 5\% critical area) $=0,3809$ for $\mathrm{n}=27$} \\
\hline & $\mathrm{X} 1$ & $\mathrm{X} 2$ & $\mathrm{X} 3$ & $\mathrm{X} 4$ \\
\hline $\mathrm{X} 1$ & 1 & $-0,0889$ & $-0,2631$ & $-0,1206$ \\
\hline $\mathrm{X} 2$ & $-0,0889$ & 1 & $-0,0831$ & $-0,0603$ \\
\hline $\mathrm{X} 3$ & $-0,2631$ & $-0,0831$ & 1 & 0,1242 \\
\hline $\mathrm{X} 4$ & $-0,1206$ & $-0,0603$ & 0,1242 & 1 \\
\hline
\end{tabular}

Source: Self-study

Table 3. Pattern and anti-pattern in normalized diagnostic characteristics

\begin{tabular}{|l|c|c|c|c|}
\hline & $\mathrm{X} 1$ & $\mathrm{X} 2$ & $\mathrm{X} 3$ & \multicolumn{1}{c|}{$\mathrm{X} 4$} \\
\hline pattern & 2,7305 & 4,7580 & 2,1119 & 2,0931 \\
\hline anti-pattern & $-1,6381$ & $-0,3319$ & $-1,7935$ & $-1,6882$ \\
\hline
\end{tabular}

Source: Self-study 
In another stage, according to the method of development pattern correlates of a pattern and anti-pattern were indicated, so the best and the weakest realization of diagnostic characteristics. These correlates were noted down in Table 3.

It constitutes a basis for indicating a value of synthetic measurement which determined a level of didactic efficiency for analysed OECD countries. These countries were segregated according to given measurement and grouped according to its intensity. The distance of these countries from a development pattern and value of an efficiency measurement was included in Table 4.

It is noticeable that a didactic efficiency measurement of higher education is rather low. Mean efficiency was estimated on a level of $25 \%$, which is not the best result. On average this measurement in chosen countries differs from an average level of about 0,08 which as a result gives differentiation on a level of $32 \%$. Among countries that have the highest efficiency we can distinguish Denmark, Hungary, Sweden and Austria. Its mean efficiency was almost 40\%. Poland, Lithuania, Slovenia, Latvia, Spain, the Czech Republic, Croatia and the Netherlands was in a second group according to their didactic efficiency (mean efficiency for these countries was 0,26 ) The weakest group of countries due to analysed phenomenon was made by Portugal, Italy and Romania.

Table 4. Pattern and anti-pattern of normalized diagnostic characteristics

\begin{tabular}{|l|c|c|}
\hline & distance from a pattern & measurement of development \\
\hline Denmark & 4,7946 & 0,4447 \\
\hline Hungary & 4,9739 & 0,4239 \\
\hline Sweden & 5,6146 & 0,3497 \\
\hline Austria & 5,6668 & 0,3437 \\
\hline Poland & 6,2230 & 0,2792 \\
\hline Lithuania & 6,2746 & 0,2733 \\
\hline Slovenia & 6,2952 & 0,2709 \\
\hline Latvia & 6,3681 & 0,2624 \\
\hline Spain & 6,3773 & 0,2614 \\
\hline Czech Republic & 6,4136 & 0,2572 \\
\hline Croatia & 6,4348 & 0,2547 \\
\hline Netherlands & 6,4573 & 0,2521 \\
\hline Belgium & 6,5440 & 0,2421 \\
\hline Germany & 6,5479 & 0,2416 \\
\hline Slovakia & 6,5481 & 0,2416 \\
\hline Ireland & 6,5747 & 0,2385 \\
\hline United Kingdom & 6,5789 & 0,2380 \\
\hline
\end{tabular}




\begin{tabular}{|l|c|c|}
\hline Cyprus & 6,6271 & 0,2324 \\
\hline Estonia & 6,6654 & 0,2280 \\
\hline Malta & 6,7560 & 0,2175 \\
\hline Greece & 6,8841 & 0,2027 \\
\hline Finland & 6,9918 & 0,1902 \\
\hline France & 7,0227 & 0,1866 \\
\hline Bulgaria & 7,0405 & 0,1845 \\
\hline Portugal & 7,3068 & 0,1537 \\
\hline Italy & 7,6970 & 0,1085 \\
\hline Romania & 7,9905 & 0,0745 \\
\hline mean & & 0,2464 \\
\hline standard deviation & & 0,0797 \\
\hline variability coefficient & & $32,35 \%$ \\
\hline
\end{tabular}

Source: Self-study

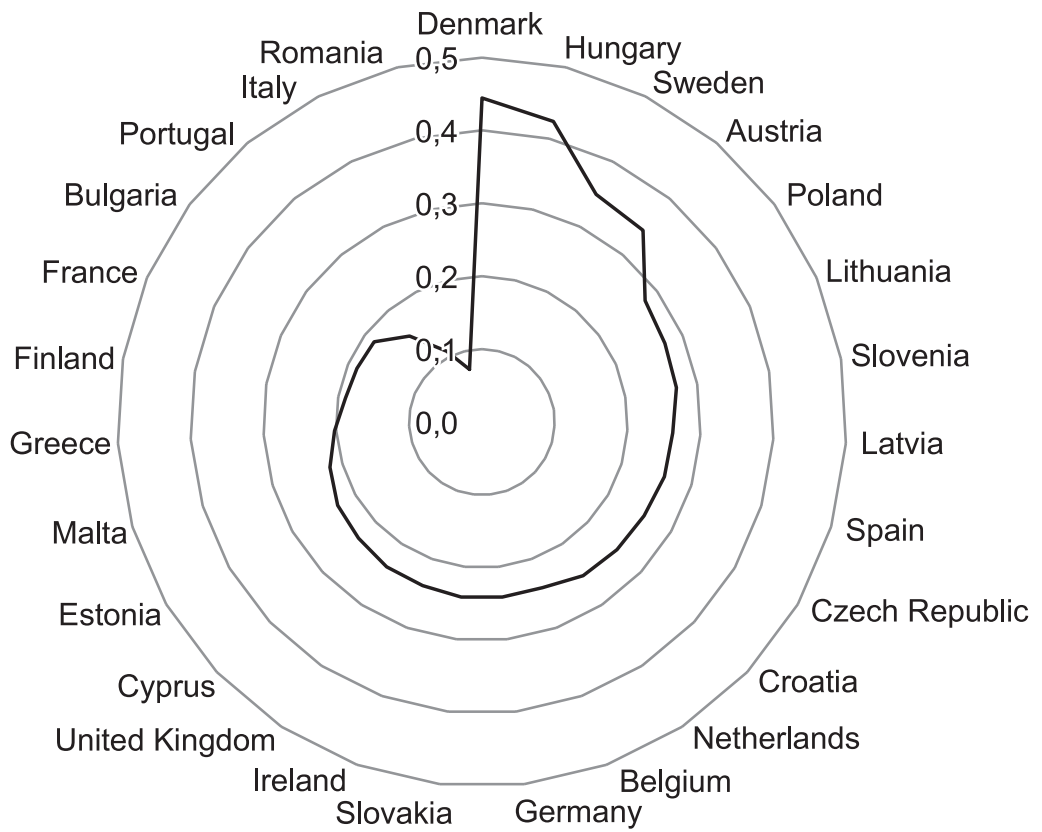

Chart 4.Measurement of a didactic efficiency of chosen OECD countries Source: Self-study 


\section{CLASSIFICATION OF CHOSEN OECD COUNTRIES ACCORDING TO THEIR DIDACTIC EFFICIENCY WITH THE USAGE OF TAXONOMIC MEASURE OF DEVELOPMENT}

\section{Summary}

Education is one of the main factors that determine social and economic growth of a country. Its high level guarantees employment and a possibility of professional development on the one hand and on the other allows for managing counties economy for those who are educated and ready for changes. In a long-term programme 'Europe 2020', taken into realization in Union countries,a key role is played by raising citizens' education. The result of realizing this strategy should be economy based on knowledge and care about social cohesion. Resources given over by a country for education should be used in an effective way by maximalization of educational effects with a given level of country financing. In conditions of a market economy, globalisation and strength of competition it is vital to effectively manage the resources that we possess. Efficiency measurement is vital not only for economic units but also for those that operate in specific conditions like universities. Efficiency evaluation in quantitative conceptualization should constitute one of a tool for making economic decision. The more precise the more thorough the economic information is.

The aim of this analysis is to compare and classify chosen European countries with reference to their didactic efficiency. This article constitutes continuation of the authors' researches.

\section{KLASYFIKACJA WYBRANYCH KRAJÓW OECD WEDŁUG ICH EFEKTYWNOŚCI DYDAKTYCZNEJ Z WYKORZYSTANIEM TAKSONOMICZNEJ MIARY ROZWOJU}

\section{Streszczenie}

Edukacja jest jednym z głównych czynników determinujących wzrost społeczny i gospodarczy kraju. Jej wysoki poziom z jednej strony gwarantuje zatrudnienie i możliwość rozwoju zawodowego, z drugiej zaś pozwala na zarządzanie gospodarką osobom wykształconym i gotowym do zmian. Realizacja długoterminowego programu „Europa 2020” w państwach Unii odgrywa kluczową rolę w podnoszeniu poziomu edukacji obywateli. Skutkiem realizacji tej strategii powinna być gospodarka oparta na wiedzy i trosce o spójność społeczną. Zasoby przekazane przez kraj o wysokim poziomie edukacji powinny być efektywnie wykorzystywane przez maksymalizację efektów edukacyjnych przy danym poziomie finansowania kraju. W warunkach gospodarki rynkowej, globalizacji i siły konkurencji kluczowe znaczenie ma więc skuteczne zarządzanie posiadanymi zasobami. Pomiar efektywności odgrywa nadrzędną rolę nie tylko dla jednostek ekonomicznych, lecz także tych, które działają w określonych warunkach, takich jak uniwersytety. Ocena efektywności w koncepcji ilościowej powinna stanowić jedno z narzędzi podejmowania decyzji ekonomicznej. Im jest ona dokładniejsza, tym dokładniejsza jest informacja ekonomiczna.

Celem tej pracy jest porównanie i klasyfikacja wybranych krajów europejskich ze względu na ich skuteczność dydaktyczną. Niniejszy artykuł stanowi kontynuację badań autorów. 